\title{
A New Methodical Treatment for Math Teaching and its Effect on Math Learning
}

\author{
Assoc. Prof. Dr. Svjetllana Kërënxhi \\ University of Elbasan, Albania \\ Faculty of Natural Sciences, Department of Mathematics \\ E-mail: skerenxhiel@yahoo.com \\ Assoc. Prof. Dr. Pranvera Gjoci \\ University of Elbasan, Albania \\ Faculty of Education Science, Department of Methodology of Teaching \\ E-mail: veragjoci@yahoo.com
}

Doi:10.5901/jesr.2013.v3n7p662

\section{Abstract}

In Albania during recent years, has been seen an increase in the attention of teachers to deepen scientific, pedagogical and methodical knowledge. Teachers have all the ways open to further training. Qualifications are designed to enable teachers in the possession and application of psycho-pedagogical knowledge. Relying on this knowledge teachers create the opportunity to review critically the personal experience of teaching and to enrich it with new ideas and didactic experiences. Also, this gives them support of creating opportunities to teachers to analyze the methods and ways of learning, assess performance gaps to understand, and most important issue even to find the right way to overcome the real difficulties that may occur during the teaching. In this context our model of dual treatments is a new experience for the teachers. We introduced the dual treatments with the teachers of elementary education, who studied for professional qualification in "Aleksandër Xhuvani" University of Elbasan, Albania during the year 2011-2012. There were included in the study 113 teachers from 487 participants. The study showed that the introduction of teachers with the model of dual treatments raised the scale of self-esteem of teachers for a better implementation of dual treatments in teaching of mathematics. The study showed also that there exists significant relation between six grades teachers' seniority and their dual treatments abilities.

Keywords: elementary education, mathematics teaching, mathematics learning, dual treatments

\section{Introduction}

The science of didactics and methodology of mathematics are studied in universities to prepare future teachers. They include methods and better forms, which are the result of the generalization of more teaching experience. The methodology of teaching process issues: in what way and why just so, should be learnt. New elements that appear and are placed in the practice of teaching enrich the essence of the methodology by giving it always a new spirit. The opportunity for the implementation of the methodology in the work of teachers depends largely on his professional training and his abilities to run the mental activity of pupils, and by making him active. To realize such an event, the teacher should be a good dominant of the elements didactics and methodology of the given subject and to implement them during teaching. The teacher should be able to select in each case the best teaching method that fits to the goals of its work, to predict the possible consequence of applying this method, always to find the way of solution to the difficulties which can arise and then make the self-analysis and assess the achievement of the goal. On the other side it is known that the thinking in general is addressed towards the things that are not known. A person is curious and he wants to learn about everything. The development of the student thinking grows considerably if the teacher alongside teaching mathematics teaches different ways of thinking and reasoning. Indeed, thinking is displayed in the ability to analyze and synthesize, to generalize and concretize and so on; that is, it is displayed in the ability to use different ways of thinking activity in the process of studying the material and of solving problems in every situation faced in the daily life. We think that these tendencies must be exerted in a positive direction during the process of teaching math, teaching the student, who is guided by the desire to get knowledge, to study the theory and the exercises from all points of view. On supporting this idea, interesting information is the evidence of dualism in science in general (Gay \& Tall, 1994; Korneyeva \& Yastrebov, 2004; Turuntayev \& Yastrebov, 2005; Valeyeva \& Yastrebov, 2009; Korthagen, 2010), and particularly in 
mathematics (Gao, 2000; Yastrebov, 2001; Yastrebov, Men'shikova \& Yepifanova, 2006; Artstein-Avidan \& Milman, 2007; Kerendzhi, 2009; Gjoci \& Kërënxhi, 2009a,b).

It is a very positive fact that in the elementary school text-books of mathematics, the concepts often are treated in duality. Meanwhile, we identify the lack of the necessary skills and knowledge to use dual treatments effectively. The teachers face with the necessity to have a theoretical instructive model for dual treatments at the level of the students at elementary education. The researchers think that the lack of experience and instructive materials about the realization of dual treatments are the main causes which lead the teacher in one-sided interpretations of the concepts and one-sided analyses of the mathematical processes. The wrong way of treatment the mathematic concepts, processes and mathematic exercises influences a lot in the partly acquisition of the knowledge from the students. These deficiencies in teaching can be reparable. That's why based on our experience in teaching, worldwide experience and in the desire to improve teaching of mathematics, we propose implementation of teaching through dual treatments. (see Gjoci, 2011, 2012a,b; Gjoci \& Kërënxhi, 2010, 2012; Kërënxhi, 2011, 2012a,b; Kërënxhi \& Gjoci, 2010, 2011).

The researchers introduced the dual treatments during 2009-2010 on 10 teachers of elementary education (grade 1-5) of some schools of Elbasan city in Albania. Five of these teachers (grade 1-5) implemented dual treatments on the average in 30\% of classes (Gjoci \& Kërënxhi, 2010). After the implementation of the model in math teaching of the first grade of elementary education and statistical elaboration of data for 221 students (the year 2009-2011), we came to the conclusion that students who are taught with dual treatments in the subject of mathematics have better results in this subject than students who have not been treated with them. The researchers included 6 lectures about "teaching through dual treatments" in the program about the qualification of teachers of elementary education in the "Aleksandër Xhuvani" University of Elbasan during the year 2011-2012. In this paper we describe briefly the lectures about dual treatments and the study about the influence of these lectures to the participant teachers.

\section{Theoretical qualification of teachers about the realization of teaching through dual treatments}

By 'dual treatment' in mathematics of elementary education, the researchers mean the dual interpretation, analysis, solution and formulation, respectively of the concept, process, exercise and problem that carries a dual nature. According to Egan, (1997) dual structuring is prominent in modern young children's thinking seems so obvious that it hardly needs pointing out. Meanwhile according to Hallpike (1979) dual oppositions are intrinsic to the process of human thought.

Dual treatments realized about three categories, which are included in the curricula and text-books of mathematics. In the $1^{\text {st }}$ category were included those concepts and relations that accept dual interpretation. By dual interpretation the researchers understand the activity through which the mathematical concept or relation is interpreted with its dual aspect. Dual interpretations of concepts or relations are the initial level of dual treatments. Dual treatments of the initial level can be applied by the teachers starting from the first topics of teaching mathematics of the first grade, where the dual concepts are present. In the $2^{\text {nd }}$ category there are included the processes and facts which can be analyzed in two different points of view or according to us, they accept the dual analysis. By dual analysis we understand the activity through which the mathematical fact or process is analyzed in two different ways. Dual analyses constitute the average level of dual treatments. The dual treatments of the average level can be applied by the teacher starting with very simple exercises after the quarter of the mathematical program of the $1^{\text {st }}$ grade had been developed. In the $3^{\text {rd }}$ category we include exercises and problems for which the students must be writing two different solutions or writing the dual problem of the given problem. In this category the researchers evaluate especially the ability of students to be used with the dual formulation of the problem and understanding that the dual problem differentiates from the opposite problem "because in the dual problem, the solution doesn't change but only the formulation does" (Gjoci \& Kërënxhi, 2010, p. 420). The combination of dual solution with the dual formulation constitutes the higher level of dual treatments. For this level the student should be able to give different solvings for these problems, to build different schemas for their solving and to give the dual problem of the given problem.

\subsection{For interpretation of dual concepts}

Referring to the curricula of elementary education in Albania and the mathematic textbook of the first grade (Dedej, et.al., 2009), the researchers observe that the meanings inside-outside are the first dual concepts which can be interpreted in duality. They can be interpreted in duality for the first time in the four lesson of the first unit (Dedej, et.al., 2009, p. 8). Teaching can be realized through the story of Little Red Cap. The teacher should be careful so that the students to become familiar with the meanings inside - outside. Continuing the illustrated fairy - tale, the students are invited to tell 
what fruit the mother have put in the basket of Red Cap and which fruit are outside the basket. Continuing the illustration of fairy - tale the students should tell for example the objects which are in the house of grandmother and what they are watching outside of the house through the window. Teaching continues with many examples given by the students. The teacher should take care of the students to become familiar with these meanings and to individualize elements of community in its internal area. The assimilation of these concepts is also important for the fact that becoming familiar with them precedes the topic on the association one by one and the topic on other dual meanings of more than-less than. The meanings more than-less than are some of the most important meanings pertaining to the understanding of the number directly related with it. They can be interpreted in duality in the sixth lesson of the first unit (Dedej, et.al., 2009, p. 10),, which studied in the second week of the school program. By using the method of accompanying one by one the elements of both units the students manage to make the comparison of the units, to come in the conclusion, which has more-less elements. In the sixth lesson of the second unit (Dedej, et.al., 2009, p. 18), which is explained and treated on the thirteenth class of the teaching program of mathematics, can be interpreted in duality for the first time the markings $>,<$, while in the seventh lesson of the second unit this two markings link two numbers by forming an inequality. Teacher should ask such questions "what do we have more" and for the same model of exercise she should ask the question "what do we have less?" In the seventh lesson of the second unit the teacher should ask the students to answer the questions: what do we have more? What do we have less? Which number is bigger? Which number is smaller? In the eighth lesson of the second unit (Dedej, et.al., 2009, p. 18), the teacher should interpret in duality the note $1<2$ : the number one is smaller than the number two and the number two is bigger than the number one. In this way the students get used to "see" the inequality in its both directions and understand that when the number 1 is smaller than the number 2 , at the same time, the number 2 is bigger than the number 1 . The length meaning is one of the main meanings that are linked directly with the distance meaning. The term of length in mathematics serves to characterize the segment and exactly its measure. Teacher should interpret in duality the meanings longer than - shorter than, using a lot of examples of comparison. For every example teacher should ask the students to answer not only to the question: "which is longer?", but also to the question: "which is shorter?".

\subsection{Analysis of dual processes. Dual problems}

Dual analysis can begin with the examples: $1+5=6$ and $6=1+5 ; 2+4=6$ and $6=2+4$ etc. In the second semester the dual analysis should be complete: numerical equalization $5+3=8$ (Dedej et.al., 2009, p. 50) shows that the sum of the numbers 5,3 is 8 , and at the same time 8 could be explained as the addition of two factors 5,3 .

Dual formulation includes the main problem and the dual problem. The teacher can formulate for the first time the dual problem according to the example: The teacher creates in the class a store where are sold flowers and puts as a seller one of the students. Then she invites Anna and Mary. The teacher tells them to buy flowers as a gift for their mother. Anna bought 6 flowers meanwhile Mary bought 4 flowers. The teacher asks the students to solve this problem: Anna bought 6 flowers meanwhile Mary bought 4 flowers. Which of the children bought more flowers? How many flowers more? After the students solved this problem, the teacher should ask the questions: Which of the children bought less flowers? How many flowers less? Solving in both models is the same despite from different formulations of the questions. Teacher should note this fact by the help of her students.Solving in duality or solving in two different ways can be applied through this example: Jenny bought 6 notebooks. Emma bought 9 notebooks. How many notebooks bought both girls together? Solve the problem in two ways. Students should give the solutions: $6+9=15=(6+4)+5=15 ; 6+9=(6+6)+3=15$.

The dual treatments, included in our model of teaching, allow the successful students to be flexible in thinking, moving in between both viewpoints, thus creating the possibility for the students to understand the existence at the opposite realities upon the same scene. If the teacher of the elementary school teaches the students to use a mental structure based on dual treatments, then such abilities come out from the students, that the students at the same time can see both realities of the same view. A student with these reflexes will be always successful in mathematics.

\section{Effect on self-esteem of teachers}

The purpose of this study was to determine the effect of instructional lections for dual treatments (DTL) on self-esteem of teachers to implement dual treatments in mathematics teaching. The main issues of this study were:

1. Are there any effects of using DTL on teacher's self-esteem for dual treatment implementation?

2. Is there a significant relation between teachers' workplace (urban/rural area) and their dual treatments abilities? 
3. Is there a significant relation between six grades teachers' seniority and their dual treatments abilities?

\section{Methodology}

\subsection{Participants}

Participants in this study were the teachers of elementary education of some 9-year schools, who studied in "Aleksandër Xhuvani" University of Elbasan, Albania, in order to be qualified during the 2011-2012 academic year. In the study took part 113 teachers selected from 487 teachers who studied in the university for professional qualification. The participants were from 9 counties (Albania is separated in 12 administrative counties): Tirana, Elbasan, Durrës, Fier, Berat, Korçë, Gjirokastër, Dibër, Kukës. Table 1 indicates the distribution of teachers into districts of the county and then in municipalities, grouped in rural and urban teachers. Table 2 indicates the other characteristics of participants of this study.

Table 1. Distribution of participants according to the counties, districts and municipalities

\begin{tabular}{|c|c|c|c|c|c|}
\hline \multirow[b]{2}{*}{ County } & \multirow[b]{2}{*}{ District } & \multirow[b]{2}{*}{ Municipality } & \multicolumn{3}{|c|}{ Workplace of teachers } \\
\hline & & & In city & In village & Total \\
\hline \multirow{2}{*}{ Berat } & Berat & Bashkia Ura-Vajgurore & 1 & 1 & \multirow[b]{2}{*}{3} \\
\hline & Skrapar & Çorovodë & 1 & 0 & \\
\hline \multirow{3}{*}{ Dibër } & Bulqizë & Shupenzë, Ostren & 0 & 2 & \multirow{3}{*}{4} \\
\hline & Dibër & Lurë & 0 & 1 & \\
\hline & Mat & Xibër & 0 & 1 & \\
\hline \multirow{2}{*}{ Durrës } & Durrës & Durrës, Shijak, Sukth, Rrashkull, Xhafzotaj & 4 & 3 & \multirow[b]{2}{*}{9} \\
\hline & Krujë & Krujë & 2 & 0 & \\
\hline \multirow{4}{*}{ Elbasan } & Elbasan & $\begin{array}{l}\text { Elbasan, Bradashesh, Gostimë, Labinot-Fushë, Labinit-Mal, Mollas, } \\
\text { Papër, Shushicë, Shalës }\end{array}$ & 12 & 14 & \multirow{4}{*}{50} \\
\hline & Gramsh & Gramsh, Kodovjat, Kukur, Poroçan & 1 & 5 & \\
\hline & Librazhd & Librazhd, Polis, Prrenjas, Stravaj, Stërblevë, Rrajcë, Hotolisht & 7 & 9 & \\
\hline & Peqin & Gjoçaj, Shezë & 0 & 2 & \\
\hline \multirow[b]{2}{*}{ Fier } & Fier & Fier, Roskovec, Kuman, Mbrostar, & 2 & 2 & \multirow[b]{2}{*}{18} \\
\hline & Lushnje & $\begin{array}{l}\text { Lushnje, Ballagat, Bubullimë, Fier-Shegan, Golem-Lushnje, } \\
\text { Karbunarë, Remas, Tërbuf }\end{array}$ & 4 & 10 & \\
\hline Gjirokastër & Tepelenë & Tepelenë & 1 & 0 & 1 \\
\hline \multirow{2}{*}{ Korçë } & Korçë & Korçë, Maliq, Voskop & 2 & 4 & \multirow[b]{2}{*}{8} \\
\hline & Pogradec & Velçan & 1 & 1 & \\
\hline Kukës & Kukës & Malzi & 0 & 1 & 1 \\
\hline \multirow{2}{*}{ Tirana } & Kavajë & Rrogozhinë, Golem, Lekaj, Luzi i Vogël & 2 & 3 & \multirow[b]{2}{*}{19} \\
\hline & Tirana & Tiranë, Kamëz, Paskuqan, Pezë, Petrelë & 8 & 6 & \\
\hline Total & 19 & $x^{2}$ & $\begin{array}{c}48 \\
42.5 \%\end{array}$ & $\begin{array}{c}65 \\
57.5 \%\end{array}$ & $\begin{array}{c}113 \\
100 \%\end{array}$ \\
\hline
\end{tabular}

Table 2. Characteristics of participants

\begin{tabular}{|l|c|c|}
\hline Variables & N & $\%$ \\
\hline Gender & 113 & 100 \\
\hline Female & 95 & 84.1 \\
\hline Male & 18 & 15.9 \\
\hline Seniority & $\mathrm{N}$ & $\%$ \\
\hline $1-5$ years & 20 & 17.7 \\
\hline $5-10$ years & 17 & 15.0 \\
\hline $10-15$ years & 15 & 13.3 \\
\hline $15-20$ years & 18 & 15.9 \\
\hline $20-25$ years & 24 & 21.2 \\
\hline $25+$ & 19 & 16.8 \\
\hline & & \\
& $-\bullet$ & \\
& 665 & \\
\end{tabular}




\subsection{Instruments and data collection}

Self-esteem was measured through self-reporting statements of teachers based in teaching as a profession. A 20-item scale was conducted to measure self-esteem. Cronbach's alpha reliability coefficient of the total scale was .90, so the scale can be considered reliable with our sample. A two-dimensional analysis is performed for self-esteem. The dimensions are called "current implementation" and "implementation in the future". The measures for "current implementation" were conducted before DTL. They were made to evaluate how much the teachers apply the dual treatments now in mathematic teaching of elementary education. The test includes ten items with a coefficient Cronbach's alpha .88. As Cronbach's alpha for each item varied from .86 to .88, all items were evaluated as acceptable. The measures for "implementation in the future" were conducted after DTL. They were made to evaluate the scale of self-esteem and the alert of teachers for dual treatments implementation in the future. The "implementation in the future" - scale consists of ten items with a coefficient Cronbach's alpha of .86. The Likert-type scale with five-option there used to measure the "current implementation" (Never $=1$, Rarely $=2$, Sometimes $=3$, Often $=4$, All of the Time $=5$ ) and level of "implementation in the future" (Strongly Disagree $=1$, Disagree $=2$, Neutral $=3$, Agree $=4$, Strongly Agree $=5$ ). Measures were made at two different times.

The intercorrelation was investigated using Pearson Product-Moment coefficient Correlation for "Comparison of sizes", "Comparison of quantities", "Comparison of lengths", "Comparison of numbers", "Dual analysis in case when the addition is until 20", "Dual analysis in case when the addition is until 100", "Dual analysis after solution of equations", "Dual analysis after solution of inequalities", "Dual solution of exercises", "Dual formulation of problems" which were measured for "current implementation". The data are shown in Table 3.

Table 3. Inter-item correlation coefficients on "current implementation"

\begin{tabular}{|l|l|l|l|l|l|l|l|l|l|l|}
\hline Measures & 1 & 2 & 3 & 4 & 5 & 6 & 7 & 8 & 9 & 10 \\
\hline (1) CS & 1.00 & & & & & & & & & \\
\hline (2) CQ & $.64^{\star \star}$ & 1.00 & & & & & & & & \\
\hline (3) CL & $.54^{\star \star}$ & $.51^{\star \star}$ & 1.00 & & & & & & & \\
\hline (4) CN & $.51^{\star \star}$ & $.52^{\star \star}$ & $.42^{\star \star}$ & 1.00 & & & & & & \\
\hline (5) DAAU20 & $.38^{\star \star}$ & $.45^{\star \star}$ & $.53^{\star \star}$ & $.46^{\star \star}$ & 1.00 & & & & & \\
\hline (6) DAAU00 & $.43^{\star \star}$ & $.55^{\star \star}$ & $.55^{\star \star}$ & $.51^{\star \star}$ & $.76^{\star \star}$ & 1.00 & & & & \\
\hline (7) DAASE & $.31^{\star \star}$ & $.39^{\star \star}$ & $.36^{\star \star}$ & $.37^{\star \star}$ & $.58^{\star \star}$ & $.52^{\star \star}$ & 1.00 & & & \\
\hline (8) DAASI & $.30^{\star \star}$ & $.42^{\star \star}$ & $.32^{\star \star}$ & $.35^{\star \star}$ & $.54^{\star \star}$ & $.53^{\star \star}$ & $.72^{\star \star}$ & 1.00 & & \\
\hline (9) DSE & $.23^{\star}$ & $.40^{\star \star}$ & $.25^{\star \star}$ & $.35^{\star \star}$ & $.41^{\star \star}$ & $.45^{\star \star}$ & $.38^{\star \star}$ & $.40^{\star \star}$ & 1.00 & \\
\hline (10) DFP & $.21^{\star}$ & $.38^{\star \star}$ & $.21^{\star}$ & $.29^{\star \star}$ & $.34^{\star \star}$ & $.34^{\star \star}$ & $.43^{\star \star}$ & $.30^{\star \star}$ &., $37^{\star \star}$ & 1.00 \\
\hline
\end{tabular}

$\mathrm{N}=113$. $\mathrm{CS}=$ Comparison of sizes scale; $\mathrm{CQ}=$ Comparison of quantities scale; $\mathrm{CL}=$ Comparison of lengths scale; $\mathrm{CN}=$ Comparison of numbers scale; DAAU20 = Dual analysis in case when the addition is until 20 scale; DAAU100= Dual analysis in case when the addition is until 100 scale; DAASE= Dual analysis after solution of equations scale; DAASI= Dual analysis after solution of inequalities scale; DSE= Dual solution of exercises scale; DFP= Dual formulation of problems scale. ${ }^{*} p<0.05,{ }^{*} p<$ 0.01 .

Different authors suggest different interpretations of Pearson Correlation coefficient. Referring Cohen (1988) we can say about "current implementation" that there are strong relationships between comparison of quantities and comparison of sizes $(41 \%)$, , between dual analysis in case when the addition is until 100 and dual analysis in case when the addition is until $20(58 \%)$, between dual analysis after solution of inequalities and dual analysis after solution of equations (52\%). Meanwhile in the Table 4 are shown the analogue data for "implementation in the future".

Table 4. Inter-ietem correlation coefficients on "implementation in the future"

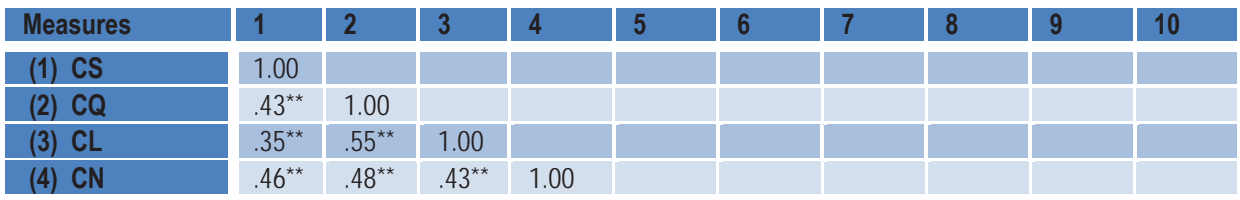




\begin{tabular}{|l|l|l|l|l|l|l|l|l|l|l|}
\hline (5) DAAU20 & $.33^{\star \star}$ & $.33^{\star \star}$ & $.22^{\star}$ & $.38^{\star *}$ & 1.00 & & & & & \\
\hline (6) DAAU100 & $.33^{\star \star}$ & $.53^{\star \star}$ & $.37^{\star \star}$ & $.37^{\star \star}$ & $.65^{\star \star}$ & 1.00 & & & & \\
\hline (7) DAASE & $.27^{\star \star}$ & $.22^{\star}$ & .15 & $.26^{\star \star}$ & $.36^{\star \star}$ & $.41^{\star \star}$ & 1.00 & & & \\
\hline (8) DAASI & .15 & $.38^{\star \star}$ & $.29^{\star \star}$ & $.23^{\star \star}$ & $.34^{\star \star}$ & $.48^{\star \star}$ & $.63^{\star \star}$ & 1.00 & & \\
\hline (9) DSE & $.30^{\star \star}$ & $.39^{\star \star}$ & $.36^{\star \star}$ & $.38^{\star \star}$ & $.37^{\star \star}$ & $.46^{\star \star}$ & $.32^{\star \star}$ & $.53^{\star \star}$ & 1.00 & \\
\hline (10) DFP & .10 & $.33^{\star \star}$ & $.33^{\star \star}$ & $.32^{\star \star}$ & $.44^{\star \star}$ & $.50^{\star \star}$ & $.38^{\star \star}$ & $.51^{\star \star}$ & $.59^{\star \star}$ & 1.00 \\
\hline
\end{tabular}

$\mathrm{N}=113$. $\mathrm{CS}=$ Comparison of sizes scale; $\mathrm{CQ}=$ Comparison of quantities scale; $\mathrm{CL}=\mathrm{Comparison}$ of lengths $\mathrm{scale}$; $\mathrm{CN}=$ Comparison of numbers scale; DAAU20= Dual analysis in case when the addition is until 20 scale; DAAU100= Dual analysis in case when the addition is until 100 scale; DAASE= Dual analysis after solution of equations scale; DAASI= Dual analysis after solution of inequalities scale; DSE= Dual solution of exercises scale; DFP= Dual formulation of problems scale. ${ }^{*} p<0.05$, ${ }^{*} p<$ 0.01 .

Even Pearson Correlations between "implementation in the future" items continue to emerge again strong relationship between dual analysis in case when the addition is until 100 and dual analysis in case when the addition is until 20 $(42 \%)$, between dual analysis after solution of inequalities and dual analysis after solution of equations (40\%) and also show very strong relationship between dual formulation of problems and dual solution of exercises (35\%) compared with $14 \%$ in "current implementation".

\subsection{Results}

The statistical analyses were done by using both descriptive statistics and inferential statistics. Although the research was designed as a survey study, to see the whole picture and to understand the interaction between the data presented descriptively, inferential statistics were also performed. The data were analyses by using the program of SPSS 17.0 package.

Regarding to $3^{\text {rd }}$ issue of study the results indicated that teachers with 10-15 years seniority in education dedicate more to dual analysis, dual solution and dual formulation while teachers with 15-25 years seniority in education dedicate more to dual interpretation. In the Table 5 is given more information for "current implementation" regarding seniority.

Table 5. "Current implementation" of dual treatments regarding seniority

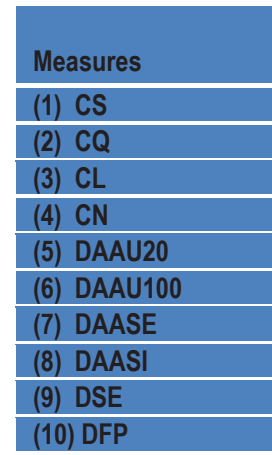

\begin{tabular}{|c|c|c|c|c|c|c|}
\hline & \multicolumn{7}{|c|}{ Mean differences } \\
\cline { 2 - 7 } Seniority & $<5$ & $5-10$ & $10-15$ & $15-20$ & $20-25$ & $>25$ \\
\hline $20-25$ & .75 & .34 & .15 & .03 & 0 & .07 \\
\hline $15-20$ & .88 & .37 & .24 & 0 & .03 & .20 \\
\hline $20-25$ & $.95^{*}$ & .34 & .02 & .19 & 0 & .01 \\
\hline $20-25$ & .82 & .46 & .41 & .04 & 0 & .24 \\
\hline $10-15$ & $1.38^{*}$ & .67 & 0 & .51 & .11 & .58 \\
\hline $10-15$ & .80 & .66 & 0 & .38 & .10 & .55 \\
\hline $20-25$ & .99 & .35 & .09 & .46 & 0 & .61 \\
\hline $10-15$ & .72 & .40 & 0 & .26 & .03 & .34 \\
\hline $10-15$ & .82 & .36 & 0 & .18 & .40 & .33 \\
\hline $10-15$ & .83 & .35 & 0 & .27 & .60 & .25 \\
\hline
\end{tabular}

$\mathrm{N}=113 . \mathrm{CS}=$ Comparison of sizes scale; $\mathrm{CQ}=$ Comparison of quantities scale; $\mathrm{CL}=$ Comparison of lengths $\mathrm{scale}$; $\mathrm{CN}=$ Comparison of numbers scale; DAAU20= Dual analysis in case when the addition is until 20 scale; DAAU100= Dual analysis in case when the addition is until 100 scale; DAASE= Dual analysis after solution of equations scale; DAASI= Dual analysis after solution of inequalities scale; DSE= Dual solution of exercises scale; DFP= Dual formulation of problems scale. ${ }^{*} p<0.05$.

In order to answer to the $1^{\text {st }}$ issue: Are there any effects of using DTL on teacher's self-esteem for dual treatment implementation? - in the Table 6 there are shown the results about the "current implementation" of dual treatments from the teachers in teaching mathematics in elementary education and results about "implementation in the future". The data are grouped according to the number of individuals and the percentage that has this number in the sample (113 teachers). 
Table 6. Items' Frequencies, Means and Standard Deviations

\begin{tabular}{|c|c|c|c|c|c|c|c|c|c|}
\hline \multicolumn{3}{|c|}{ MEASURES } & 1 & 2 & 3 & 4 & 5 & M & SD \\
\hline \multirow{5}{*}{ 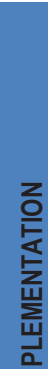 } & 1. Comparison of sizes & $\begin{array}{l}\mathrm{N} \\
\%\end{array}$ & $\begin{array}{l}0 \\
0\end{array}$ & $\begin{array}{c}16 \\
14.2\end{array}$ & $\begin{array}{c}37 \\
32.7\end{array}$ & $\begin{array}{c}44 \\
38.9\end{array}$ & $\begin{array}{c}16 \\
14.2\end{array}$ & 3.53 & 0.907 \\
\hline & 2. Comparison of quantities & $\begin{array}{l}\mathrm{N} \\
\%\end{array}$ & $\begin{array}{c}2 \\
1.8\end{array}$ & $\begin{array}{c}19 \\
16.8\end{array}$ & $\begin{array}{c}36 \\
31.9\end{array}$ & $\begin{array}{c}33 \\
29.2\end{array}$ & $\begin{array}{c}23 \\
20.4\end{array}$ & 3.5 & 1.053 \\
\hline & 3. Comparison of lengths & $\begin{array}{l}\mathrm{N} \\
\%\end{array}$ & $\begin{array}{c}2 \\
1.8\end{array}$ & $\begin{array}{l}11 \\
9.7\end{array}$ & $\begin{array}{c}50 \\
44.2\end{array}$ & $\begin{array}{c}29 \\
25.7\end{array}$ & $\begin{array}{c}21 \\
18.6\end{array}$ & 3.5 & 0.965 \\
\hline & 4. Comparison of numbers & $\begin{array}{l}\mathrm{N} \\
\%\end{array}$ & $\begin{array}{l}1 \\
.9\end{array}$ & $\begin{array}{c}21 \\
18.6\end{array}$ & $\begin{array}{c}33 \\
29.2\end{array}$ & $\begin{array}{c}30 \\
26.5\end{array}$ & $\begin{array}{c}28 \\
24.8\end{array}$ & 3.56 & 1.085 \\
\hline & $\begin{array}{l}\text { 5. Dual analysis in case when } \\
\text { the addition is until } 20\end{array}$ & $\begin{array}{l}\mathrm{N} \\
\%\end{array}$ & $\begin{array}{c}7 \\
6.2\end{array}$ & $\begin{array}{c}26 \\
23.0\end{array}$ & $\begin{array}{c}30 \\
26.5\end{array}$ & $\begin{array}{c}39 \\
34.5\end{array}$ & $\begin{array}{l}11 \\
9.7\end{array}$ & 3.19 & 1.09 \\
\hline \multirow{5}{*}{ 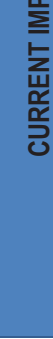 } & $\begin{array}{l}\text { 6. Dual analysis in case when } \\
\text { the addition is until } 100\end{array}$ & $\begin{array}{l}\mathrm{N} \\
\%\end{array}$ & $\begin{array}{c}6 \\
5.3\end{array}$ & $\begin{array}{c}27 \\
23.9\end{array}$ & $\begin{array}{c}32 \\
28.3\end{array}$ & $\begin{array}{c}36 \\
31.9\end{array}$ & $\begin{array}{c}12 \\
10.6\end{array}$ & 3.19 & 1.082 \\
\hline & $\begin{array}{l}\text { 7. Dual analysis after solution } \\
\text { of inequalities }\end{array}$ & $\begin{array}{l}\mathrm{N} \\
\%\end{array}$ & $\begin{array}{c}16 \\
14.2\end{array}$ & $\begin{array}{c}27 \\
23.9\end{array}$ & $\begin{array}{c}35 \\
31.0\end{array}$ & $\begin{array}{c}25 \\
22.1\end{array}$ & $\begin{array}{l}10 \\
8.8\end{array}$ & 2.88 & 1.174 \\
\hline & $\begin{array}{l}\text { 8. Dual analysis after solution } \\
\text { of equations }\end{array}$ & $\begin{array}{l}\mathrm{N} \\
\%\end{array}$ & $\begin{array}{c}19 \\
16.8\end{array}$ & $\begin{array}{c}36 \\
31.9\end{array}$ & $\begin{array}{c}37 \\
32.7\end{array}$ & $\begin{array}{c}16 \\
14.2\end{array}$ & $\begin{array}{c}5 \\
4.4\end{array}$ & 2.58 & 1.067 \\
\hline & 9. Dual solution of exercises & $\begin{array}{l}\mathrm{N} \\
\%\end{array}$ & $\begin{array}{c}9 \\
8.0\end{array}$ & $\begin{array}{c}46 \\
40.7\end{array}$ & $\begin{array}{c}34 \\
30.1\end{array}$ & $\begin{array}{c}18 \\
15.9\end{array}$ & $\begin{array}{c}6 \\
5.3\end{array}$ & 2.7 & 1.008 \\
\hline & $\begin{array}{l}\text { 10. Dual formulation of } \\
\text { problems }\end{array}$ & $\begin{array}{l}\mathrm{N} \\
\%\end{array}$ & $\begin{array}{c}16 \\
14.2\end{array}$ & $\begin{array}{c}39 \\
34.5\end{array}$ & $\begin{array}{c}43 \\
38.1\end{array}$ & $\begin{array}{c}13 \\
11.5\end{array}$ & $\begin{array}{c}2 \\
1.8\end{array}$ & 2.52 & 0.936 \\
\hline \multirow{10}{*}{ 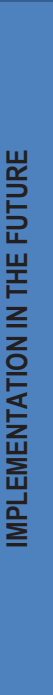 } & 1. Comparison of sizes & $\begin{array}{l}\mathrm{N} \\
\%\end{array}$ & $\begin{array}{l}0 \\
0\end{array}$ & $\begin{array}{c}5 \\
4.4\end{array}$ & $\begin{array}{c}9 \\
8.0\end{array}$ & $\begin{array}{c}75 \\
66.4\end{array}$ & $\begin{array}{c}24 \\
21.2\end{array}$ & 4.04 & 0.686 \\
\hline & 2. Comparison of quantities & $\begin{array}{l}\mathrm{N} \\
\%\end{array}$ & $\begin{array}{l}1 \\
.9\end{array}$ & $\begin{array}{c}2 \\
1.8\end{array}$ & $\begin{array}{c}15 \\
13.3\end{array}$ & $\begin{array}{c}60 \\
53.1\end{array}$ & $\begin{array}{c}35 \\
31.0\end{array}$ & 4.12 & 0.765 \\
\hline & 3. Comparison of lengths & $\begin{array}{l}\mathrm{N} \\
\%\end{array}$ & $\begin{array}{l}0 \\
0\end{array}$ & $\begin{array}{c}2 \\
1.8\end{array}$ & $\begin{array}{c}20 \\
17.7\end{array}$ & $\begin{array}{c}60 \\
53.1\end{array}$ & $\begin{array}{c}31 \\
27.4\end{array}$ & 4.06 & 0.723 \\
\hline & 4. Comparison of numbers & $\begin{array}{l}\mathrm{N} \\
\%\end{array}$ & $\begin{array}{l}0 \\
0\end{array}$ & $\begin{array}{c}6 \\
5.3\end{array}$ & $\begin{array}{c}15 \\
13.3\end{array}$ & $\begin{array}{c}51 \\
45.1\end{array}$ & $\begin{array}{c}41 \\
36.3\end{array}$ & 4.12 & 0.836 \\
\hline & $\begin{array}{l}\text { 5. Dual analysis in case when } \\
\text { the addition is until } 20\end{array}$ & $\begin{array}{l}\mathrm{N} \\
\%\end{array}$ & $\begin{array}{l}1 \\
.9\end{array}$ & $\begin{array}{l}10 \\
8.8\end{array}$ & $\begin{array}{c}28 \\
24.8\end{array}$ & $\begin{array}{c}55 \\
48.7\end{array}$ & $\begin{array}{c}19 \\
16.8\end{array}$ & 3.72 & 0.881 \\
\hline & $\begin{array}{l}\text { 6. Dual analysis in case when } \\
\text { the addition is until } 100\end{array}$ & $\begin{array}{l}\mathrm{N} \\
\%\end{array}$ & $\begin{array}{c}2 \\
1.8\end{array}$ & $\begin{array}{l}11 \\
9.7\end{array}$ & $\begin{array}{c}30 \\
26.5\end{array}$ & $\begin{array}{c}59 \\
52.2\end{array}$ & $\begin{array}{l}11 \\
9.7\end{array}$ & 3.59 & 0.863 \\
\hline & $\begin{array}{l}\text { 7. Dual analysis after solution } \\
\text { of inequalities }\end{array}$ & $\begin{array}{l}\mathrm{N} \\
\%\end{array}$ & $\begin{array}{c}4 \\
3.5\end{array}$ & $\begin{array}{c}12 \\
10.6\end{array}$ & $\begin{array}{c}35 \\
31.0\end{array}$ & $\begin{array}{c}49 \\
43.4\end{array}$ & $\begin{array}{c}13 \\
11.5\end{array}$ & 3.49 & 0.955 \\
\hline & $\begin{array}{l}\text { 8. Dual analysis after solution } \\
\text { of equations }\end{array}$ & $\begin{array}{l}\mathrm{N} \\
\%\end{array}$ & $\begin{array}{c}3 \\
2.7\end{array}$ & $\begin{array}{c}20 \\
17.7\end{array}$ & $\begin{array}{c}42 \\
37.2\end{array}$ & $\begin{array}{c}39 \\
34.5\end{array}$ & $\begin{array}{c}9 \\
8.0\end{array}$ & 3.27 & 0.938 \\
\hline & 9. Dual solution of exercises & $\begin{array}{l}\mathrm{N} \\
\%\end{array}$ & $\begin{array}{c}3 \\
2.7\end{array}$ & $\begin{array}{l}10 \\
8.8\end{array}$ & $\begin{array}{c}40 \\
35.4\end{array}$ & $\begin{array}{c}46 \\
40.7\end{array}$ & $\begin{array}{c}14 \\
12.4\end{array}$ & 3.51 & 0.917 \\
\hline & $\begin{array}{l}\text { 10. Dual formulation of } \\
\text { problems }\end{array}$ & $\begin{array}{l}\mathrm{N} \\
\%\end{array}$ & $\begin{array}{c}4 \\
3.5\end{array}$ & $\begin{array}{c}21 \\
18.6\end{array}$ & $\begin{array}{c}40 \\
35.4\end{array}$ & $\begin{array}{c}38 \\
33.6\end{array}$ & $\begin{array}{l}10 \\
8.8\end{array}$ & 3.26 & 0.98 \\
\hline
\end{tabular}

The statistics show that DTL influenced in the self-esteem of the teachers by shifting median from level "Sometimes=3" (current implementation) in level "Agree=4" (implementation in the future). Mean scale is shifted from 31.12 (current implementation) to 37.18 (implementation in the future).

Paired sample t-tests (also called repeated measures) are used in order to understand changes between scores from Time 1- "current implementation", at Time 2- "implementation in the future" (after after some intervention or event) which are shown in Table 7. 
Table 7. Paired sample t-tests

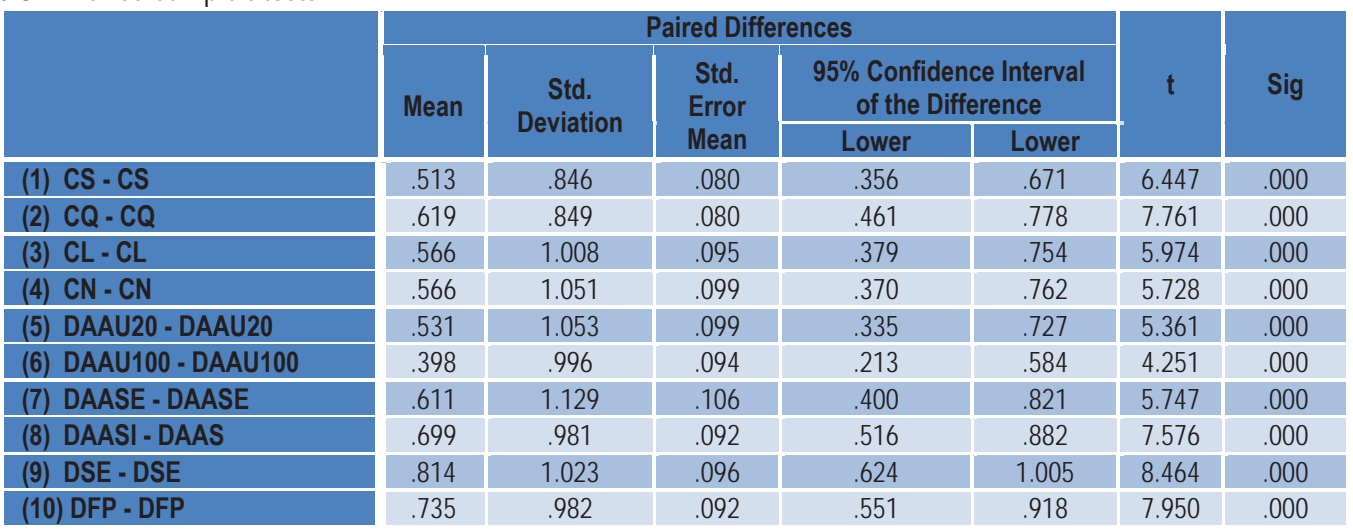

$\mathrm{CS}=$ Comparison of sizes; $\mathrm{CQ}=$ Comparison of quantities; $\mathrm{CL}=$ Comparison of lengths; $\mathrm{CN}=$ Comparison of numbers; $\mathrm{DAAU} 20=$ Dual analysis in case when the addition is until 20; DAAU100= Dual analysis in case when the addition is until 100; DAASE= Dual analysis after solution of equations; DAASI= Dual analysis after solution of inequalities; DSE= Dual solution of exercises; DFP= Dual formulation of problems.

Table 7 shows a statistically important effect from the "current implementation" to "implementation in the future" for each of measured items 1-10. This shows that DTL should be included in the cycle of lectures about the qualification of elementary school teachers. In the graph 1 there are shown the differences that created DTL from Time 1- "current implementation" in Time 2- "implementation in the future" in dual interpretations, dual analysis, dual solutions and dual formulations.

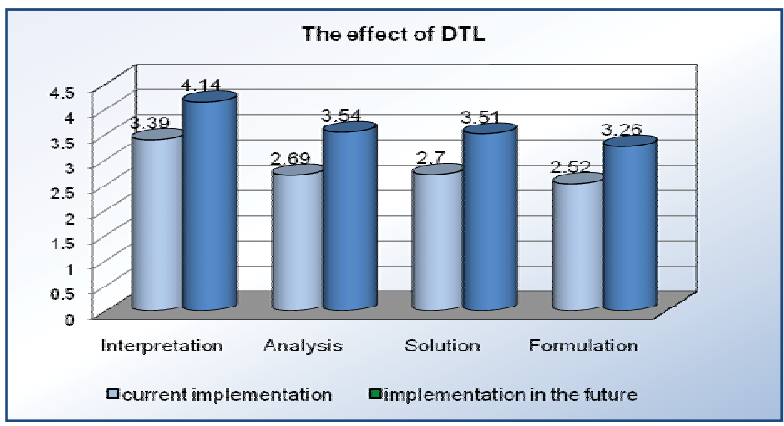

Graph 1. The Effect of DTL in dual interpretation, analysis, solution, formulation scale

\section{Discussions and conclusions}

Our Dual Treatments Model, which starts with the dual interpretation and dual analysis of the symbols, continues with other dual treatments, inspired by research done after 2000. In this period are investigated the dual properties of mathematics and their reflection in this kind of teaching. These studies concluded that dual properties of mathematics can be easily illustrated by a simple material included in actual standards of education. After we concluded that the mathematic curriculum for elementary education in Albania is rich with models which accept dual treatment (see Gjoci \& Kërënxhi, 2010) we did the study with the teachers of elementary education (2011-2012). This study is done in order to see in which scale teachers apply dual treatments in mathematic. The study continued with the same group of teachers even after qualification with DTL. The results showed that these lectures had a statistically important effect in the growth of self-esteem of the teachers for the implementation in the future of dual treatments in teaching (mean scale statistics was raised from $M=11.30$ to $M=14.45$ ). In the study was used quantity method for the realization of research, concretely the technique of questionnaires for data collection. The number of distributed questionnaires was 130 , collected 122 , from which resulted as valuable for statistical analysis 113. Despite that teachers taught in the city (42.5\%) and in village 
(57.5\%) the workplace didn't effect on "current implementation" of dual treatments and not even in alert of dual treatments' implementation "implementation in the future" (issue 2). This helped that the qualification with DTL to be without differentiating: teachers in village/teachers in city. Statistics show that there is an important relationship between scales $3,4,5$ of seniority of teachers and their ability to make dual treatments (issue 3 ). So teachers who have $10-25$ years in education apply better dual treatments. Concluding we can say that since statistics showed an important effect from "current implementation" to "implementation in the future" (issue 1) DTL should be included in the lectures for the qualification of the teachers in elementary education.

\section{References}

Artstein-Avidan, Sh., \& Milman, V. (2007). A characterization of the concept of duality. Electronic Research Announcements in Mathematical Sciences, 14, 42-59.

Cohen, J.W. (1988). Statistical power analysis for the behavioral sciences (2nd edn). Hillsdale, NJ: Lawrence Erlbaum Associates.

Dedej, K., Koci, E., Spahiu, E., \& Konçi, Z. (2009). Matematika 1: për klasën e parë të shkollës 9-vjeçare. Tiranë: SHBLSH e Re.

Egan, K. (1997). The Educated Mind: How Cognitive Tools Shape Our Understanding. University of Chicago Press.

Gao, D.Y. (2000). Duality principles in nonconvex systems: Theory, Methods and Applications. Boston/Dordrecht/London: Kluwer Academic Publishers.

Gjoci, P. (2011). Primary school curriculum enables the inclusion of dual interpretations in mathematics In V. Timovski (Ed.), The modern society and education, Vol 2 (pp. 983-990). Skopje: Pedagoški fakultet Sv. Kliment Ohridski.

Gjoci, P. (2012a). Teaching mathematiks based on dual treatment and the effect of this method on students' success. In N. Ognjevska (Ed.), Yearbook: Science - Education - Art, Vol 6 (pp. 45-53). Union of Scientists - Blagoevgrad.

Gjoci, P. (2012b). Treatment of mathematics' dual meanings in first grade of primary education for the formation of 'gestalt intuition'. In S. Divljan (Ed.), Methodological aspects of mathematics II (pp. 43-51). Jagodina: Pedagogical Faculty of Science-University of Kragujevac.

Gjoci, P., \& Kërënxhi, S. (2009a). Some new elements of methodology of teaching in primary education. In H. Asutay \& E. (Budak) Bayir (Ed.), Education in Balkans Today, Vol 1 (pp. 457-460). Edirne: Trakya Üniversitesi.

Gjoci, P., \& Kërënxhi, S. (2009b). Aspects of dualism in teaching process. In G. E. Lasker (Ed.), Advances in Education, Vol IX (pp. 2329). Ontario, Canada: IIAS.

Gjoci, P., \& Kërënxhi, S. (2010). Dual interpretations in primary education mathematics as aspect of critical thinking of students. Odgojne Znanosti - Educational sciences. 2(20), 413-426.

Gjoci, P., \& Kërënxhi, S. (2012). Efektet e modelit Intuita Gestalt në mësimdhënie. Buletini i Shkencave Natyrore, FSHN, UT, (online). $14,15-26$.

Gray, E.M., \& Tall, D.O. (1994). Duality, ambiguity, and flexibility: A proceptual view of simple arithmetic. Journal for Research in mathematics education, 26(2), 115-141.

Hallpike, C.R. (1979). The foundations of primitive thought. Oxford: Clarendon Press.

Kerendzhi, S. (2009). Professional orientation of the teaching of mathematical analysis in the Faculty of Economics. Hearld of the University of the Russian Academy of Education (in Russian), 3 (46), 101-103.

Kërënxhi, S. (2011). Implementation of dual interpretations in the mathematics of first grade. In V. Timovski (Ed.), The modern society and education, Vol 2 (pp. 991-998). Skopje:: Pedagoški fakultet Sv. Kliment Ohridski.

Kërënxhi, S. (2012a). Duality and its influence on the teaching of mathematics. In N. Ognjevska (Ed.), Yearbook: Science - Education Art, Vol 6 (pp. 53-60). Union of Scientists - Blagoevgrad.

Kërënxhi, S. (2012b). Formation of 'gestalt intuition' through mathematics teaching in primary education. In S. Divljan (Ed.), Methodological aspects of mathematics II (pp. 31-41). Jagodina: Pedagogical Faculty of Science-University of Kragujevac.

Kërënxhi, S., \& Gjoci, P. (2010). Interpretimet duale gjatë mësimit të matematikës. Buletini Shkencor, Universiteti "Fan S. Noli" Korçë, 19, 181-190.

Kërënxhi, S., \& Gjoci, P. (2011). Modeli Intuita Gestalt në mësimdhënien e matematikës së arsimit fillor. Buletini Shkencor UNIEL, 3(33), 28-49.

Korthagen, F.A.J. (2010). Situated learning theory and the pedagogy of teacher education: Towards an integrative view of teacher behavior and teacher learning. Teaching and Teacher Education, 26, 98-106.

Korneyeva, Ye.N., \& Yastrebov, A.V. (2004). Invariant properties of psychology and their reflection in the process of teaching. Yaroslavl Pedagogical Bulletin, 12, 124-134.

Turuntayev, S.A., \& Yastrebov, A.V. (2005). Manifestations of dualistic properties of physics in teaching specific subjects. Yaroslavl Pedagogical Bulletin (in Russian), 2, 114-120.

Valeyeva, N.A., \& Yastrebov, A.V. (2009). Dualistic properties of the stories and their reflection in the teaching of history in secondary schools. Yaroslavl Pedagogical Bulletin (in Russian), 1, 24-31.

Yastrebov, A.V. (2001). Dualistic properties of mathematics and their reflection in the teaching process. Yaroslavl Pedagogical Bulletin (in Russian), 1, 48-53.

Yastrebov, A.V., Men'shikova, N.A., \& Yepifanova, N.M. (2006). Identification of the dualistic properties of science in teaching elementary mathematics. Yaroslavl Pedagogical Bulletin (in Russian), 4, 87-93. 